\title{
The Opportunities and Challenges of Islamic Accounting Learning for Vocational Students and Its Application in Islamic Microfinance Institutions
}

\author{
Arim Nasim, Agus Widarsono, Ellinna Riennovita \\ Universitas Pendidikan Indonesia \\ arim.nasim@upi.edu
}

\begin{abstract}
HR needs in the field of Islamic Economy by 2017 is 20,838 people per year. Nevertheless, the average number of $\mathrm{S} 1$ and S2 graduates of Islamic Economy Study Program is 6,542 per year. Hence, there's a gap of 14,296 per year. Most of the needs, especially for BMT and Sharia Cooperative, can be fulfilled from vocational-graduated skilled labors. This study aims to find out the development of Islamic accounting and its teaching effectiveness in vocational schools to meet the needs of accounting manpower. The method used is qualitative research with case study approach. The Data were collected from the 12th grade students and the graduates of the accounting vocational schools in West Java Province, comprising 26 Regencies and Cities, Teacher, Islamic Experts and director of BMT. Source triangulation technique is used to test the credibility. The result shows that the characteristics of Islamic accounting applied in BMT is unique, because The legal status of BMT is cooperative, based on Cooperative Accounting Guides, it has to comply SAK ETAP (Financial Accounting Standards for Entities Without Public Accountability). On the other hand, because BMT is a sharia entity that performs sharia transactions, BMT has to obey SAK Syariah (Islamic Financial Accounting Standards). Hence, BMT in Indonesia may use both SAK Syariah and SAK ETAP. It is necessary to provide learning module for produces graduate off professional accounting technicians for BMT.
\end{abstract}

Keywords-islamic economy, islamic accounting standards, sharia cooperative, vocational schools, learning module.

\section{INTRODUCTION}

The dynamic development of financial accounting standards in Indonesia must be accompanied by a continuous learning process for accounting practitioners. In fact, this continues improvement is not only obliged to the accountants, but the teachers, as the educators, also have to conform their teaching materials to the Indonesian accounting standards.

Before 2010 the Financial Accounting Standards regulate account-based financial reporting and special accounting reports for certain entity, such as plantation, cooperative, banking and sharia entity. However, since 2010 massive changes has happened in Indonesian accounting standards. Financial accounting standards classify reporting standards into three types: IFRS-based, Financial Accounting Standards for Entities Without Public Accountability (SAK ETAP) and Islamic Accounting Standards (SAK Syariah)
These standards are applied to a go-public company. Financial statement harmonization is the main issue for businesspeople. This harmonization is especially needed when a company expands their business to another country that applies different standards from ones of their origin country. The different process of assessment, recording and financial statement disclosure may bias the information that mislead the users. As a result of globalization, the Association of International Accountants set up the International Financial Reporting Standards (IFRS). The Indonesian Institute of Accountants (IAI) immediately responds this change by adopting the IFRS concept to the national financial accounting standards. Previously, the standards was oriented to the US GAAP (General Accepted Accounting Principle). In addition, IAI also sets up accounting standards for small business and Islamic financial institution.

Financial Accounting Standards for Entities without Public Accountability (SAK ETAP) is the latest product of IAI. The issuance of SAK ETAP is based on the cost-benefit analysis. If a small company uses the IFRS-based accounting standards, they will have problems both on human and financial resources. The concept of IFRS is very complex that it needs a skilled person to prepare an IFRS-based report in details. A small business doesn't really need a complex information as a public company does. Therefore, the SAK ETAP is set up.

In line with the rapid growth of Islamic Banking, the Indonesian Institute of Accountants set up standards for shariabased enterprises and institutions. The standards are set because of the fundamental differences between commercial accounting and Islamic accounting. For example, interest is not allowed in Islamic law. The rapid growth of Islamic financial institutions requires skilled manpower that comprehend and apply Islamic accounting.

Not only PSAK, IFRS, ETAP materials that have to be disseminated to the teachers, but also the IT-based preparation of financial statements. The concept of eco-friendly teaching is also a strategic issue needed to address quickly. A manual financial statement is not only complicated to prepare and control, but also not eco-friendly for it consumes a bunch of papers. Hence, a special software is required to prepare a financial statement compliant with the latest accounting standards. 
The rapid growth of Islamic Banking and Non-Bank Financial Institutions demands skilled manpower that are capable of preparing financial statements compliant with the principles of Islamic accounting. According to Yuslam Fauzie, until now in Indonesia there are 11 Islamic banks (BUS), 23 Islamic business units (UUS), 160 BPRS, 5,500 BMT and 4,000 sharia cooperatives as well as Non-Bank Financial Institutions like Islamic insurance and Islamic capital market with 203 issuers. Year 2007-2013: The average needs for manpower for Islamic Banking (BUS, UUS and BPRS) is 6,150 per year. Assuming HR growth is $30.9 \%$ per year, the HR needs by 2017 is $\mathbf{2 0 , 8 3 8}$ per year. Nevertheless, the average number of S1 and S2 graduates of Islamic Economy Study Program is 6,542 per year. Hence, there's a gap of 14,296 per year. Most of the needs can be fulfilled from vocational-graduated skilled labors. [1]

Accounting educators have an important role in the transfer knowledge from the teachers/lecturers to the students. They are required to conform the regulations of financial statement preparation. Therefore the vocational students are expected to be able to prepare financial statements for Islamic financial institutions, especially Islamic microfinance institutions like BMT and sharia cooperative. They are prepared for work, so they have to be able to prepare financial statements the increasing needs for report preparation for SMEs is an opportunity for them to offer their service to the Islamic microfinance institutions. The changes in reporting regulations for SMEs compel the vocational teachers to be capable of teaching Islamic Accounting Standards (SAK Syariah). To help the teachers and students acquire learning materials of SAK Syariah, a web-based learning media needs to provide.

The previous study only explained about the different of Islamic accounting and conventional accounting [2-4]. This research have contribute to explain about implementation Islamic accounting in Islamic micro financial institution and finally this research was result a module of study

Based on this, it is needed a model and comprehensive learning media of accounting with regard to the development and needs of the industrial world. . The rapid growth of information technology forces the businesspeople to use it to produce a qualified, accurate, reliable, relevant and up-to-date information. Most of accounting module is not created based on a real case in an organization, this study aims to find out the development of Islamic accounting and its teaching effectiveness in vocational schools to meet the needs of accounting manpower.

\section{LITERATURE REVIEW}

\section{A. Islamic Accounting}

One of Islamic Economic Systems that has been growing rapidly is the Financial Institutions-Bank or Non-Bank. This rapid growth demands an accounting system to report transactions compliant with sharia principles, because sharia serves as a reference ethic that requires assessment and selection of accounting practices. Studying Islamic accounting is a must in running the more globalized economy [5]. Hameed defines Islamic accounting as an accounting process which provides relevant information (not only limited to financial data) to the stakeholders of an entity to ensure it continuously operates according to sharia principles and achieves the purpose of socio-economic [6].

If we compare the definition of Islamic accounting to the conventional one, the difference will be more clearly. Conventional accounting is a process of identifying, recording, classifying, interpreting and communicating economic events to certain users to make decisions with. Based on this, Hameed distinguish the Islamic one from the conventional one for three reasons: (1) the purpose of providing information, (2) the type of identified information and the way of measuring, assessing, recording and communicating it (3) to whom the information is delivered (users). Conventional accounting aims to provide information mainly for allocating the available resources efficiently based on market efficiency hypothesis used by the users in making buy or sell decision for their investment. On the other hand, Islamic accounting aims to ensure that an Islamic organization complies the sharia principles and tries to achieve a certain socio-economic purpose compliant with Islam. Based on the purpose, Islamic accounting has to be holistic in the financial and non-financial reporting by considering the economic events and transactions, social, environment and religion aspects to measure and report/disclose. [7]

Meanwhile, Triyuwono formulates the "material" purpose of sharia financial statement is to provide information to make economic decisions, while the "spirit" one is to provide accountability. Both is mutually inclusive, in which one cannot negate the other and they are united. Triyuwono (2002) argues that Islamic accounting is an instrument used by the management to provide accountability to God (vertical accountability) and to stakeholders and environment (horizontal accountability). Regarding information to provide/disclose by Islamic accounting, Triyuwono (2002: 214) states that: "Please note that the provision of information is not only limited to the quantitative one, as in modern accounting, but also covers the qualitative one, whether economically, socially, spiritually or politically." [8]

Baydoun and Willet also emphasize the importance of the accountability to God and society as the purpose of Islamic accounting.

The focal concepts of ownership in Islam are different from that of the typical western interpretation. According to Sharia, individuals are only trustees for what they own. God is the ultimate owner of the all wealth (Qur'an 6:165, 57:7). Although individuals have the right to own resources that are made available by God, the right is not absolute. This tenet has a direct impact on the objective of accounting from an Islamic point of view. Accountability is seen as being personal accountability to God. Accountability from the traditional western perspective, of course, is being interpreted by being accountable to private stakeholder. In an Islamic accounting system, accountability may be interpreted as being accountable to the society at large. [9]

According to Baydoun and Willet, Islamic accounting holds two essential principles, which are full disclosure and 
social accountability, derived from sharia accountability of every Muslim to the whole society. Based on these principles, Baydoun and Willet, consider the Western disclosure framework limited to the accountability to the society only. It is because the disclosure of financial statements is only limited to historical cost, and ignores the potential relationship between the entity and the vast social environment. [10]. Baydoun and Willet argue that the focus of Islamic accounting is different to one of Western accounting, so that full disclosure is absolutely needed by Islamic accounting.[11]

Yaya states that it is needed an extensive overhaul to change conventional accounting into Islamic. He believes that the conventional accounting has failed to achieve the socioeconomic purpose in Islam. The socio-economic in Islam is the cornerstone of every Islamic jurisprudence/law related to economic issues. On the other hand, the current economic issues is very complicated, and most of them are not directly regulated by sharia principles. For example, capital market is not directly regulated by sharia. However, based on socioeconomic purpose, the regulations can be specified. [12]

Taheri (2000) in his article entitled The Basic Principles of Islamic Economy and Their Effects on Accounting Standards Settings states that accounting policy for Islamic accounting tends to be value-oriented. This is due to the three basic components of Islamic economy: multi ownership, limited economic freedom and social justice. Based on these, the financial statement should aim to fulfill the interest of the management, public and country.[13]

.Meanwhile, Harahap proposes Conceptual Structure Theory containing the purpose of Islamic accounting. The purpose includes muamalah (amar ma'ruf nahi munkar, justice and righteousness), social benefit, cooperation, the elimination and precaution of riba and the encouragement of zakah [14]. In line with Harahap's, Hameed emphasizes the importance of Islamic accounting purpose to provide information regarding zakah calculation, justice enforcement and to report countersharia activities. This purpose needs to achieve in order to fulfill the accountability to both direct and indirect stakeholders [hameed]. Whereas Khan states that the purpose of accounting information for sharia banks is different from the conventional ones for the following reasons: (1) sharia banks are closely associated to sharia framework, so that their transactions are different from the conventional ones; (2) the users of sharia banks information have a different purpose from those of conventional. The users of sharia banks information are not only direct stakeholders, such as shareholders, investors, Sharia Supervisory Board, central bank and government, but also indirect stakeholders, such as general public, non-Muslim observers, researchers and employees. Therefore, the disclosed information is not only for direct stakeholders, such as information that helps evaluate the ability to maintain asset, liquidity, profitable resources and sharia compliance, but also information regarding the accountability to the employees, customers, public, and environment. [15]

\section{B. The Definition of Learning System}

M. Rohman and Sofan, explains that:
System is an integral unity of a number of components, in which they influence each other and have their own functionalities. However, their functionalities lead to a sole purpose of the system itself.

Learning is said a system, because it is an activity that aims to make the students learn. The learning process is a series of activities involving various components. Thus, the educators need to comprehend it, at least the purpose and the expected outcome.

\section{Factors that Affect the Learning System}

Several factors affect the implementation of a learning system. According to Rohman and Sofan, the factors are, among others:

\section{1) The Factor of Teacher}

Teachers is a critical component in the implementation of a learning strategy. Without them, no matter how good or ideal, a strategy is not possible to apply. Teacher is a professional work, so it requires special skills. A teacher must really master the ins and outs of education, pedagogy and other knowledge, in order to carry out their duties well and provide the best outcome.

\section{2) The Factor of Student}

Students is a unique organism that develops gradually. They grow the whole aspects of their personality. However, the speed and rhythm of each individual development are not always the same. In addition to the characteristics of a student, these affect the learning process as well.

\section{3) The Factor of Means and Infrastructure}

Means is all equipment's and properties, such as buildings, classrooms, desks, chairs, learning tools and media, which are directly used and support the education process, especially teaching and learning activities. Whereas infrastructure is all facilities, such as schoolyards, gardens and roads to school, which are indirectly support the education process. However, these facilities may be directly used for the process of learningteaching, for example, school gardens for biology teaching and schoolyards for sport fields. [16]

\section{RESEARCH METHOD}

This study used qualitative methods with Case Study Approach. Qualitative research is defined as research process that uses in inductive data analysis to learn about the meaning that participant hold about a problem or issues by identifying pattern or themes. [17]

The population of this study is the 12 th grade students and the graduates of the accounting vocational schools in West Java Province, comprising 26 Regencies and Cities. The sample of this study is only 10 Regencies and Cities. The sampling technique used is non probability sampling, specifically purposive sampling. Descriptive statistics is used to analyze data to answer the first identified problem. It is numbers that are a kind of statistics used to analyze data by describing collected data as they are, without trying to make any general conclusion. It includes data presentation through charts, graphs, pie charts, pictogram; modus, median and mean calculations; decile and percentile calculation; data spread 
through median calculation, standard deviation and percentage calculation. The Miles and Huberman model is used to analyze data in the qualitative method. The model consists of three stages: data reduction, data display, and conclusion drawing or verification. Triangulation technique is used to test the credibility of data, specifically source triangulation, by confirming the comprehension to various sources as follows [18] :

Fig. 1. Triangulation Technique

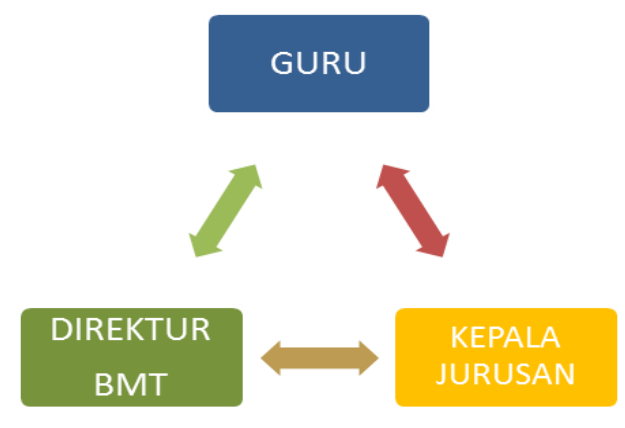

\section{RESULT AND DISCUSSION}

A. The Development of Islamic Accounting Standards and the Needs for Teaching of Islamic Accounting Subject in Vocational Schools

Islamic Banking accounting in Indonesia is guided by PSAK (Statement of Financial Accounting Standards) No. 59 adopted from AAOIFI (Accounting and Auditing Organization for Islamic Financial Institutions) based in Abu Dhabi, UAE. AAOIFI has issued the accounting and auditing standards for Islamic financial institutions since 1998.

PSAK (Statement of Financial Accounting Standards) No. 59 is a statement issued by the Indonesian Institute of Accountants (IAI) regarding Islamic Banking Accounting. The standards are mainly oriented to AAOIFI. This DSAK-IAI product has to be appreciated since it is the beginning of Islamic accounting recognition and existence. This PSAK was passed on May 1, 2002, effective from January 1, 2003 or accounting period ended in 2003.

SAK May 2002 explains: "PSAK No. 59 is the cradle of Islamic accounting standards. PSAK No. 59 regarding Islamic Banking Accounting has been passed on May 1, 2002 by the Financial Accounting Standards Board (DSAK). Although PSAK 59 is no longer valid, but this is the milestone of our need for Islamic accounting."

The essence of PSAK 59 is that this statement aims to regulate accounting treatment (recognition, assessment, presentation and disclosure) for typical transactions of Islamic banks' activities. This statement is applied for Islamic banks, Islamic rural banks and Islamic branch of conventional banks operating in Indonesia. General matters that are not regulated in this statement refer to other PSAKs and/or accepted accounting principles which are not violating Islamic principles.

This statement is not a regulation for financial statement preparation that is based on the statutory of government, watchdog agency, and central bank (Bank Indonesia). A complete financial statement of Islamic banks consists of balance sheet, income statement, cash flow, changes in equity, changes in bound investment, zakah, infaq and sadaqah fund statement, qardhul hasan fund statement, and notes to financial statements.

PSAK no. 59 was only valid for 5 years, and the specific standards for Islamic accounting were finally set up. The followings are the reasons of PSAK 59 revocation: 1) PSAK 59 was considered no longer accommodating the rapid growth of Islamic accounting; 2) Islamic accounting is not only limited to the presentation of financial statements, but also covers several Islamic laws; 3) Islamic Banking has grown rapidly, so better standards are needed; 4) Typical standards of Islamic Banking are needed, even though they are still a part of SAK; 5) The specification of Islamic accounting standards is a serious step in developing economy in Indonesia, especially Islamic Banking; 6) The specific standards of sharia is expected to attract investors.

As time goes by, Islamic economics starts to become a focus of financial institutions. Not only as an alternative to conventional shortcomings, but it has become a solution to solve economic problems. Therefore, Islamic accounting is absolutely needed to complement the rapid growth of Islamic economy.

A better PSAK Syariah will encourage a better accounting system that generates trusted information. The maturity of PSAK Syariah impacts on the development of Islamic Financial Institutions.

As of today Indonesian Institute of Accountants (IAI) has issued 9 PSAK Syariah as follows: sharia financial statement presentation, murabahah accounting, salam accounting, istishna accounting, mudharabah accounting, musyarakah accounting, ijarah accounting, Islamic insurance, and zakah, infaq and sadaqa accounting (has not been issued yet been ratified).

These basic frameworks provide concepts that underlie the preparation and presentation of financial statements for their users. The frameworks serves a reference for: 1) The standards makers of Islamic financial accounting in delivering their duties; 2) The presenters of financial statements in resolving Islamic accounting issues that has not been regulated in Islamic financial accounting standards; 3) Auditors in giving opinion whether the financial statements comply with the applied Islamic accounting principles; and 4) The users in analyzing information provided in the financial statements compliant with the Islamic financial accounting standards.

As of today Indonesian Institute of Accountants has issued three accounting standards: SAK Umum (FAS-General), SAK Syariah (FAS-Sharia) and SAK ETAP (FAS-EWPA). The Islamic Microfinance Institutions in Indonesia are unique. Legally, the status of almost all BMTs in Indonesia is cooperative. Before 2011, the financial accounting standards of cooperatives refer to PSAK 27 regarding Cooperative 
Accounting. In line with changes, the accounting standards are divided into 3 types described above. DSAK issued Revocation Statement of Financial Accounting Standards no. 8 (PPSAK 8) on the revocation of PSAK 27 regarding Cooperative Accounting. Through the regulation of State Minister for Cooperatives Small and Medium Enterprises (Permen KUKM) Number 04/per/M.KUKM/VII/2012 regarding Cooperative Accounting Guides, the minister defines cooperatives to use SAK ETAP. So cooperatives in Indonesia, including BMT, generally use SAK ETAP.

The transaction characteristics of BMT are rather different from other cooperatives. Since BMT is an Islamic entity that performs sharia transactions like ones in Islamic banking, BMT is obliged to comply with SAK Syariah, because SAK ETAP does not regulate sharia transactions. Hence, BMT in Indonesia may use both SAK Syariah and SAK ETAP. Beside SAK Syariah and SAK ETAP, to perform accounting process on their transactions, BMT refers to government regulations regarding cooperative accounting that don't violate sharia prin ciples. Beside Permen KUKM No.04/per/M.KUKM/VII/2012 regarding Accounting Guides, the state also issued Permen KUKM No. 35.2/PER/M.KUKM/X/2007 regarding Standard Operating Procedures for Management of Islamic Financial Services Cooperative or Islamic Financial Services Unit.

Given the need for many professional accounting technicians to employ in approximately 5,500 BMTs and 4,000 Islamic cooperatives and the limited time and curriculum in vocational schools, a learning of Islamic accounting that is quick and easy to understand by the vocational graduates is needed to meet the need for manpower.

\section{B. The Effective Learning of Islamic Accounting}

This study also aims to find out the importance of SAK Syariah learning, the problems of learning process and the effective learning of SAK Syariah in vocational schools. Using qualitative method, the writer conducted in-depth interviews with informants, who are the experts in accounting education, and BMT directors, who are the employers of accounting technicians.

1) The Importance of SAK Syariah Learning in Vocational Schools

Vocational school (SMK) is a secondary school that aims to provide graduates who are ready to work at technical level. The accounting vocational school is a part of it which aims to produce graduates who are ready to work in accounting and administration departments. Currently, accounting is dynamically growing in line with the development of existing businesses, including sharia-based business. Global business development indeed needs an international accounting standards. International Accounting Standard Board (IASB), based in Europe, has set up International Financial Reporting Standard (IFRS) to use globally. Indonesian accounting standards board has decided to adopt IFRS in convergence (gradually) up to the current period. In fact, not all companies in Indonesia has a global scope in running their business. Many companies are still considered small and medium companies. The Indonesian Financial Accounting Standards Board considered the implementation of IFRS is not relevant for the latter companies, so the Board issued the new standards called Financial Accounting Standards for Entities Without Public Accountability (SAK ETAP).

Islamic business practices that are different from the conventional ones require its own regulations. Therefore, the Financial Accounting Standards Board issued specific standards, the Islamic Accounting Standards (SAK Syariah), for the preparation of financial statements for sharia-based enterprises.

The implementation of SAK Syariah facilitates them in preparing the relevant financial statements for their users. The accounting vocational schools, which aim to produce graduates who are ready to work at technical level, need some learning process that relates SAK ETAP to SAK Syariah. Based on the interview with informants, this study gained understanding regarding the importance of SAK Syariah learning in accounting vocational schools.

a) Providing a Deep Comprehension of the Appropriate Accounting Standards for Certain Entities

A learning about financial accounting standards at vocational level is important to improve the quality of the graduates. It can be in form of standard introduction or giving exercises relevant with the applied standards. Nowadays accounting is not only growing as a tool to record financial transactions, but also to provide relevant information for the users of financial statements. Therefore, to provide the useful information for them, it is required accounting standards.

The applied accounting standards in Indonesia include the IFRS-based Financial Accounting Standards, Financial Accounting Standards for Entities Without Public Accountability and Islamic Accounting Standards.

Knowing the appropriate standards for an entity may allow the students to help them achieve their goals. This is important because nowadays accounting does not only present information in the financial statements, but also provides other information enabling the users to comprehend the condition of a company. Although vocational students are now widely employed by big company at technical and administrative levels, from sales and inventory record keeping, cash register to petty cash, and not to prepare comprehensive financial statements and notes to the financial statements, but in the future the career of vocational school graduates will go up and the comprehension of accounting standards to produce comprehensive financial statements will be needed.

\section{b) Organizing A Competency Test for Professional} Accounting Technicians

Competency test is organized to obtain early professional competence through appropriate education, special education, professional training and examinations in relevant subjects, plus work experience for vocational graduates.

The test is in the form of certification test for class XII students who will complete their study. Professional Accounting Technician Certification test is organized by LSPTA in cooperation with BNSP to test a person's mastery on a certain competency standard, and a certificate will be issued for those who pass. The benefits are 1) to measure the level of a 
person's mastery on a certain competency standard; 2) to gain physical evidence in the form of a certificate professional competence; 3 ) to increase the value of a person in the field of accounting.

\section{c) Preparing Ready-to-Work Individuals for Islamic} Business Enterprises

Vocational graduates are mostly employed by small or medium company rather than big company. Small company tends to employ workers that are capable of maximizing the wealth of the company. The company usually employs workers for technical purposes, so vocational graduates are needed. The government programs and banking policies make the company the target of financing, in which requiring financial statements. In the future vocational school graduates are not only employed to record financial transactions, but will be encouraged to improve their competence to develop a simple system that prepares financial statements for small and micro enterprises. Since the transaction recognition, the measurement of a value, the information presentation and disclosure in the financial statements are based on accounting standards for entities without public accountability, the preparation of financial accounting system for small and micro enterprises must comply with these standards.

\section{d) Improving Financial Statements}

The information presented in the financial statements must be qualified, relevant, reliable, up-to-date and comprehensive. The comprehension of Islamic accounting standards may allow accounting vocational graduates to help a small or micro enterprise improve the quality of their financial statements. The statements are not only used by external parties, such as banks, but also used internally by the company to assess their own performance. Head of the company may take right decisions based on the information prepared in the financial statements.

All the time, the internal solely focus on the company's income statement, without paying attention to other information that is actually required by the company, such as information on the company's assets in the form of receivables or fixed assets. Such information can be useful for the company in the corporate credit application, because these assets can be used as collateral. The weakness of a small enterprise typically lies in the separation of financial transactions committed by corporate and personal. A good accounting system provide qualified information regarding the increment of company assets derived from business transactions and separate it from the owner's personal interests. The comprehension of SAK Syariah may allow the students to improve the quality of financial statements to make it relevant for the internal and external in making strategic decisions.

\section{2) The Problems of Education Implementation}

In the implementation of education, there's always problems to face. They are not only faced in SAK Sharia learning, but also in general education. Based on interviews with informants, the problems are as follows:

a) New Curriculum Implementation, Especially in the Assessment Process
Curriculum changes have a significant impact on learning process involving teachers and students. Students are required to undertake a more active role through discovery learning. Thus, it makes the assessment process more complex. Similarly, in the implementation of 2013 curriculum strategy, the assessment is considered a problem for teachers in applying the new curriculum. The availability of detailed guides on assessment is still low, so that teachers are required to be more creative.

The new curriculum also causes problem in setting the terms of reference for the education plan. There are some changes in the delivery of materials, added or removed, at certain levels. Having been accustomed to the pattern of SBC curriculum, teachers find it difficult to implement the new curriculum, because it takes a lot of time to adjust.

To implement the SAK Syariah learning, it is required an in-depth study on its delivery, because it is closely related to learning outcomes set out in the 2013 curriculum. The learning can be delivered in a special session of accounting standards introduction for vocational students without having to put it in a more specialized subject, so that in line with the aim to produce vocational graduates who are capable to work as a technical personnel of administrative and accounting.

\section{b) The Limitations of Teachers in Creating An Effective Learning Method}

One that affects the effectiveness of the learning process is the method used by the teachers. Teachers should be able to create an attractive learning method that is not monotonous and does not make students bored while studying. The problem is that the available human resources are still weak in creating creative ideas to achieve the goal of learning easily.

This problem may be minimized through training for teachers to create attractive learning methods and or the provision of IT-based independent learning media for teachers. For example, teachers can create a method to remember a concept by creating an effective word or so called "mnemonics." They should also be able to give an actual and familiar example to make the students understand easily. In addition to lectures, they should be a mediator for the students to express ideas, solve problems and criticize the realities better. All of these will be achievable if the teachers always update their knowledge.

In regards to SAK Syariah learning, the challenge for teachers is to introduce it in a simple language to make the students easily understand. If the students read it themselves, they will face difficulty, because the language used in accounting standards is usually normative. Teachers should be able to deliver SAK Syariah materials in a language that is familiar to them. In accounting standards, the important things generally discussed are the recognition, measurement, presentation and disclosure that are indispensable in the preparation of financial statements. Hence, the teacher should introduce first the functions of financial accounting standards and the key points contained.

c) The Limitations of Computer Equipments and Learning Media for Student 
In this technological era, manual accounting is hardly found. The company usually uses computerized accounting, whether by MS Excel for the simple one or a dedicated accounting software. Small enterprises usually use MYOB, Zahir, etc. So, computerized tools are important to introduce to the students to improve their skill. The limited number of computers in each school is still a major problem in the process of learning. A number of schools have not been able to provide an adequate number of computers, so multiple students use a computer together when practicing accounting in the lab.

The other problem is the availability of learning modules that are relevant to the development of accounting standards, whereas the modules allow the students to understand the material faster and better. For example, not all teachers use the PowerPoint when presenting materials in the class. Some teachers still deliver materials manually by using a whiteboard that costs a lot of time to explain something. It turns out that teachers require a training for preparing a PowerPoint learning material to improve the quality of their teaching.

The other learning media is exercise module that usually doesn't fully represent the reality of accounting process in a company. In regards to SAK ETAP, it is required a learning module regarding standards obliged by the Financial Accounting Standards Board to improve the quality of the statements. The learning media should also be able to represent the general accounting system used by entities without public accountability. The accounting system should also be able to describe the forms, documents, records, transaction procedures within the company, including the internal control undertaken by the company.

In addition to exercises, a game approach, such as the Monopoly game board, may also be used to study accounting. In fact, a miniature of a company, such mini-bank or minicooperative, can be used as a learning media to take the students to the miniature of company transactions. They can directly interact in it by taking part as an accounting and administrative technician. Company visit and internship are the other popular learning media that are considered effectively giving a comprehension of accounting and company business.

d) The Low Involvement of Teachers in Research on Competence Development

The involvement of teachers in research is still low, whereas their research may provide huge implications in learning process. The research may help teachers to solve various problems and obstacles in the learning process, because they are the ones who really know the realities of the process. Support from academia, such as professors, research institutions, community service and other government agencies, may increase the creativity of the teachers to engage in various studies.

Teachers may not only research on teaching and learning process, but also on the development of accounting material. In regards to SAK ETAP, the teacher can also contribute in researching the value relevance of the standards.

3) The Learning Process of SAK Syariah in Vocational Schools
Based on the description of the importance and problems of SAK Syariah learning in vocational schools above, the implementation of SAK Syariah learning is conducted as follows:

a) The Providing Training and Learning For Teachers to Update Their Knowledge about Financial Accounting Standards Development

Teachers need a training on SAK Syariah material, because they have to comprehend the materials first before delivering them in order to make the students understand faster and better.

\section{Materials}

b) Developing Learning Strategies for SAK Syariah

The SAK Syariah learning can be delivered in a special session of accounting standards introduction for vocational students without having to put it in a more specialized subject. This introduction should cover:

\section{- The Scope of SAK Syariah}

Teachers have to first give the students an idea that the SAK Syariah is only used by companies that run their business with the Islamic principles.

- The Function and Application of Islamic Accounting Standards

Teachers should be able to explain the aims of the standard. In this sense, it can improve the quality of the information, because it has a comparability that can describe the company's performance better.

- The Components and Elements of Financial Statements Based on SAK Syariah

Teachers should be able to explain the elements of financial statements based on SAK Sharia and its difference from other SAKs.

- The Options of Accounting Policy and Accounting Problem Solving by Referring To Applied Standards

Teachers should be able to explain that the accounting standards will refer to the recognition, measurement, presentation and disclosure in the financial statements. In this case, accounting standards describe policy options that can be applied consistently by the company. Teachers should also be able to explain how to use accounting standards in preparing financial statements. So, whenever students face any accounting problems, they can refer to the applied standards.

A deep comprehension on the standards is not really necessary for the vocational students, because they are prepared for being an accounting and administrative technician. However, companies using SAK ETAP and SAK Syariah may employ those who want to work in Islamic microfinance institutions.

c) Developing An Applicative Learning Module Based on SAK Syariah

An applicative learning module that is based on SAK Syariah is needed by the vocational students. Therefore, the 
basic exercise of accounting subject should be associated with the implementation of the standards, so that students will have a better comprehension on accounting process.

\section{d) Implementing and Evaluating Learning Strategies}

Once compiled, the teacher can implement the SAK Syariah learning module in accounting lab with the help of MS Excel to make it easier for students in working the reporting paper. Furthermore, teachers are also required to evaluate the applied learning strategies to continuously improve the learning process.

The results of this study reinforce previous research results that Islamic Micro Finance istitution have not yet tapped some of the sources of funds .[19] and expanding Islamic banking to the poor could foster development under the right application. [20]

\section{CONClusions, IMPlicATion ANd Limitations OF THE STUDY}

\section{A. Conclusions}

This study gives an overview of the teaching practice of Islamic accounting and required competencies for BMT in vocational schools. Based on interview, literature study, and observation on learning-teaching process in vocational schools and the required competencies for the BMT, the professional technicians are they who meet competency standards. They earn their early professional competence through appropriate education, special education, professional training and examinations in relevant subjects, plus work experience. So, to achieve effective learning process for accounting vocational students prepared for employment in the BMT, the details of transactions, the characteristics of the KJKS-based accounting need to be well-comprehended, and a periodical training and internship in BMT need to be held. For the time allocation for accounting subject, especially accounting for BMT, is limited, it is necessary to provide "Crash Course" learning module to make the learning process effective. This allows the students to quickly acquire the BMT accounting procedure, from recording transactions to financial statement preparation. Special internship in BMT is needed to give them field experience. This study has created a comprehensive module to meet those needs.

\section{B. Implications and Limitations of the Study}

This study may contribute to the development of effective learning strategies of Islamic accounting in vocational schools that generates economic agents who cling to implement the Islamic principles and laws in economic transactions. This study has many limitations, including a small number of respondents and simple research method. Thus, the writer encourages the next researcher to develop the method and add the number of respondents, from students to teachers to other school officials, to obtain a comprehensive picture of the implementation of Islamic accounting learning.

\section{REFERENCES}

[1] Yuslam Fauzi, Islamic Economic and financial : Prospect, challenges and the role of univercity, Paper, universitas Pendidikan Indonesia, 2013.

[2] Kamla, Rania, Sonja Gallhofer, and Jim Haslam. "Islam, nature and accounting: Islamic principles and the notion of accounting for the environment." Accounting Forum. Vol. 30. No. 3. Elsevier, 2006..

[3] Hameed, Sahul. "From conventional accounting to Islamic accounting: Review of the Development Western Accounting Theory and Its Implications for and Differences in the Development of Islamic Accounting." Islamic-finance. net (2009).

[4] Rizal Yaya, Would the objective and characteristic of islamic Accounting for Bussness organization meet the Islamic socio -economic objective ? JAAI Volume 8 No. 2, Desember 2004

[5] Harahap, formulation of islamic accounting theory. Jakarta Pustaka Kuantum, 1999

[6] Hameed. Islamic Accounting, New Push.www Islamic_accounting.com,. 2003

[7] Hameed. Islamic Accounting, New Push.www Islamic_accounting.com,. 2003

[8] Triyuwono, Iwan.. Perspektif, Methodology, and Islamic Accounting theory. Jakarta: Rajawali Pers.,2009

[9] Baydoun and Willet. Islamic accounting theory. The AAANZ annual Conference, 1994

[10] Baydoun and Willet. (1994). Islamic accounting theory. The AAANZ annual Conference, 1994

[11] Baydoun and Willet. Islamic Corporate Report. ABACUS Vol 36, 2000

[12] Yaya Rizal. "From Conventional Accounting to Islamic Accounting, Does It Need A Slight or An Extensive Overhaul?." Jurnal Akuntansi dan Auditing Indonesia 5.2, 2001.

[13] Taheri, Mohammad R. The basic principles of Islamic Economy and their effects on accounting standards-setting, 2003

[14] Harahap, formulation of islamic accounting theory. Jakarta Pustaka Kuantum,1999

[15] Khan, M. Accounting Issues and Concepts for Islamic Banking. Paper presented at the International Conference on Developing Accounting Standards for Islamic Banks, London-1994

[16] Muhammad Rohman and Sofan. Amri, startegy and design development of learning system, Prestasi Pusta Karya, Jakarta , 2013

[17] Sarah Lewis, Qualitative Inquiry and Research Design: Choosing Among Five Approaches, Centers for Disease Control and Prevention, Atlanta, GA, USA.

[18] Sugiyono, " Qualitative and quantitative research methods." Penerbit Alfabeta,(2010.

[19] Ahmed, Habib. "Financing microenterprises: An analytical study of Islamic microfinance institutions." Islamic economic studies 9.2 (2002): 27-64.

[20] Dhumale, Rahul, and Amela Sapcanin. "An application of Islamic banking principles to microfinance." Technical Note, A study bt yhe Regional Bureau for Arab States, UNDP, in cooperation with the Middle East and North Africa Region, World Bank (1999). 